\title{
Bumil Sigap di Era Pandemi Covid 19
}

\author{
Nur Fadjri Nilakesuma ${ }^{1}$, Novria Hesti ${ }^{2}$, Dewi Susilawati ${ }^{3}$, Ramadhani Hafsah \\ Qonita $^{4}$, Yeni Gea ${ }^{5}$ \\ 1,2,3,4,5 Prodi Kebidanan Program Sarjana dan Prodi Bidan program Profesi \\ 1,2,34,5 STIKes MERCUBAKTIJAYA Padang, Surau Gadang, Kec. Nanggalo, Kota \\ Padang, Sumatera Barat 25173, Padang \\ *e-mail: nurfadjrink@gmail.com
}

Informasi Artikel

Diterima Redaksi : 23 Januari 2020

Revisi Akhir : 3 Januari 2021

Diterbitkan Online : 28 Januari 2021

Kata Kunci:

Bumil, pandemi, covid-19

\section{PENDAHULUAN}

Virus Severe Acute Respiratory Syndrome Coronavirus-2 (SARSCOV2) atau yang lebih dikenal dengan nama Coronavirus disease 2019 (COVID-19) adalah penyakit yang sedang mewabah hampir di seluruh dunia saat ini. Penyakit ini dimulai dari daerah Wuhan, provinsi Hubei, Tiongkok (POGI, 2020). Data dari website WHO tanggal 17 Agustus 2020 didapatkan kasus konfirmasi sebanyak 21.516.760 dengan total kematian 766.663 orang (WHO,2020).

Infeksi COVID-19 dapat menimbulkan gejala ringan, sedang atau berat. Gejala klinis utama yang muncul yaitu demam (suhu $>38^{\circ} \mathrm{C}$ ), batuk dan kesulitan bernapas. Selain itu dapat disertai dengan sesak memberat, fatigue, mialgia, gejala gastrointestinal seperti diare dan gejala saluran napas lain. Setengah dari pasien

\section{Abstrak}

Virus Severe Acute Respiratory Syndrome Coronavirus-2 (SARSCOV2) atau yang lebih dikenal dengan nama Coronavirus disease 2019 (COVID-19) adalah penyakit yang sedang mewabah hampir di seluruh dunia saat ini. Infeksi COVID-19 dapat menimbulkan gejala ringan, sedang atau berat. Masyarakat harus masif untuk edukasi dan diikuti dengan sanksi untuk menurunkan PR Covid 19. Edukasi ini bisa dilakukan oleh para professional (IDI, IBI, PPNI, Kesmas,MUI, DMI dan lain - lain). Tanpa edukasi yang baik, maka PR akan terus meningkat. Tujuan kegiatan pengabdian adalah memberikan edukasi tentang pedoman ibu hamil di era pandemic covid 19 dan tanda bahaya kehamilan kepada ibu hamil di PMB bidan Silvia Novita Sari Amd.,Keb tanggal 30 September - 1 Oktober 2020. Hasil kegiatan menunjukkan adanya peningkatan pengetahuan Ibu hamil tentang pelayanan maternal dan neonatal di era pandemic covid 19 dan tanda tanda bahaya dalam kehamilan. Diperlukan edukasi secara holistik terhadap seluruh ibu hamil yang tidak hadir pada saat kegiatan pengabdian sehingga ibu hamil di wilayah PMB tersebut meningkatkan kewaspadaan dalam penyebaran virus covid 19 ..

timbul sesak dalam satu minggu. Pada kasus berat perburukan secara cepat dan progresif, seperti ARDS, syok septik, asidosis metabolik yang sulit dikoreksi dan perdarahan atau disfungsi sistem koagulasi dalam beberapa hari. Pada beberapa pasien, gejala yang muncul ringan, bahkan tidak disertai dengan demam. Kebanyakan pasien memiliki prognosis baik, dengan sebagian kecil dalam kondisi kritis bahkan meninggal (KANNAN, S., et al.,2020)

S. Khan, et al, 2020).

Indonesia termasuk Negara yang terkena virus ini. Data di tanggal 16 Agustus 2002, didapatkan 139. 549 jiwa terkonfirmasi positif covid 19 dan 6150 jiwa meninggal dunia. Situasi menghadapi bencana nasional non alam COVID-19 ini memberikan dampak terhadap pelayanan kesehatan maternal dan neonatal baik secara akses maupun kualitas. 
Dikhawatirkan, hal ini menyebabkan adanya peningkatan morbiditas dan mortalitas ibu dan bayi baru lahir.

Sumatera Barat mencatat sebagian kecil ibu hamil terkonfirmasi covid 19 setelah terpapar oleh keluarganya. Ibu hamil memiliki risiko lebih tinggi untuk terjadinya penyakit berat, morbiditas dan mortalitas dibandingkan dengan populasi umum, karena kehamilan membuat ibu menjadi rentan terserang pathogen pernafasan yang mengakibatkan radang paru - paru. Perubahan ini termasuk peningkatan konsumsi oksigen, peningkatan diafragma, dan edema pernapasan saluran mukosa, yang menyebabkan wanita hamil memiliki intoleransi terhadap hipoksia (Pedro Castro et al, 2020) (Pradip et al, 2020).

Saat ini, Indonesia telah menerapkan pola hidup New Normal setelah beberapa pekan melakukan Pembatasan Sosial Berskala Besar (PSBB) dengan tujuan menurunkan angka konfirmasi covid 19. Namun, penerapan pola hidup new normal ini tidak berjalan dengan baik, sehingga prevalensi rate (PR) nya meningkat. Masyarakat harus masif untuk edukasi dan diikuti dengan sanksi untuk menurunkan PR Covid 19. Edukasi ini bisa dilakukan oleh para professional (IDI, IBI, PPNI, Kesmas,MUI, DMI dan lain - lain). Tanpa edukasi yang baik, maka PR akan terus meningkat (Direktorat Kesehatan Keluarga, 2020)

Praktik Mandiri Bidan (PMB) Silvia Nova Sari merupakan salah satu PMB diwilayah kerja Puskesmas Air Dingin Kelurahan Balai Gadang Kecamatan Koto Tangah Kota Padang. Semenjak diberlakukannnya Pembatasan Sosial Berskala Besar oleh pemerintah Kota Padang, PMB tidak melayani pemeriksaan kehamilan. Hal ini disebabkan oleh Kecamatan Koto Tangah termasuk 5 Kecamatan pertama yang masyarakat nya terkonfirmasi positif covid 19. Beberapa hari kemudian kasus positif covid 19 di kawasan ini meningkat tajam dari 2 kasus menjadi 11 kasus. Kelurahan Balai Gadang saat ini berdasarkan data Humas.Kota Padang terdapat 11 kasus terkonfirmasi positif, 1 kasus meninggal dan 8 kasus sembuh (Humas Kota Padang, 2020)
Berdasarkan perbincangan dengan pemilik PMB, masyarakat mengeluhkan tentang kemana mereka harus mencari dan mendapatkan pelayanan maternal dan neonatal jika PMB ditutup, apalagi disaat ibu hamil menemukan kelainan selama kehamilannya. Hal ini lah yang mendasari pemiliki PMB untuk membuka kembali PMB nya untuk memberikan pelayanan asuhan kebidanan. Disamping karena permintaan masyarakat untuk membuka kembali layanan kebidanan, salah satu alasan penting lainnya adalah untuk mengedukasi ibu hamil dan keluarga terhadap covid 19 dan persiapan menghadapi persalinan di era covid 19, sehingga jika terjadi kegawatdaruratan saat kehamilan dan persalinan, ibu dan keluarga telah paham dan bersedia dirujuk sehingga mengurangi keterlambatan dalam rujukan.

Berdasarkan hal diatas, maka kegiatan PKM ini dipandang perlu untuk dilakukan .

\section{METODE}

Pengabdian Masyarakat ini dilakukan dengan pemberian informasi dan edukasi kepada ibu hamil tentang "BUMIL SIGAP di Era Pandemi COVID 19" dengan sub materi tentang pedoman ibu hamil di era pandemic covid 19 dan tanda bahaya kehamilan. Kegiatan ini dilakukan secara bertahap (2 tahapan) dengan masing - masing jumlah peserta 4-5 orang ibu hamil per tahap. Kegiatan ini dilakukan dengan tatap muka, mengingat tidak semua ibu hamil di lingkup kerja PMB memiliki handphone dan perangkat elektronik yang memadai untuk dilakukan secara daring dengan aplikasi ZOOM di tanggal 30 September 1 Oktober 2020. Selain itu, juga dilakukan survei kepuasan mitra terhadap kegiatan yang sudah dilakukan.

Untuk mengetahui efek dari edukasi yang dilakukan maka tim pengabdi memberikan instrumen pre-test saat sebelum kegiatan edukasi dilakukan, sedangkan posttest setelah kegiatan. Pertanyaan yang digunakan saat pre test sama dengan pertanyaan saat post test dengan jumlah pertanyaan sebanayk 15 butir yang terdiri dari 10 pertanyaan tentang covid 19 dan pedoman anteanatal selama covid 19 dan 5 butir pertanyaan 
tentang tanda bahaya kehamilan. Setelah melaksanakan pretest, tim pengabdi membagikan masker, faceshield dan handsanitaizer bagi ibu hamil. Tim pengabdi membantu ibu hamil memasangkan faceshield.

Saat pemberian materi, tim pengabdi menggunakan alat bantu lembar balik "BUMIL SIGAP DI ERA PANDEMI COVID 19" yang telah disusun oleh tim pengabdi, banner "Bumil Sigap Cegah Covid 19" dan buku KIA.

Setelah materi edukasi diberikan, sasaran kegiatan ini kembali mengisi kuisioner post test untuk mengukur apakah terjadi peningkatan pengetahuan sasaran tentang covid 19, pedoman bagi ibu hamil di era covid 19 dan tanda bahaya kehamilan sesudah diberikan tindakan. Disamping itu, sasaran juga diminta untuk mengisi kuisioner survey kepuasan mitra/sasaran.

\section{HASIL DAN PEMBAHASAN}

Kegiatan pengabdian masyarakat ini dilaksanakan dengan memberikan informasi dan edukasi pedoman ibu hamil di era pandemic covid 19 dan tanda bahaya kehamilan. Kegiatan edukasi dilakukan sebelum bidan pemilik PMB melakukan pemeriksaan kehamilan.

Hasil analisa tim Pengabdi menunjukkan bahwa terjadi peningkatan pengetahuan yang cukup besar antara sebelum dan setelah dilakukan edukasi pengetahuan tentang covid - 19, pedoman antenatal selama covid -19 dan tanda bahaya kehamilan. Berikut diagram yang menunjukkan sebelum dan setelah kegiatan edukasi seperti pada gambar berikut :

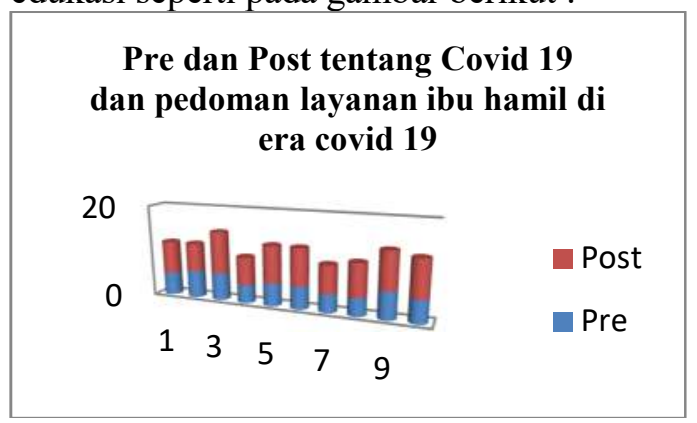

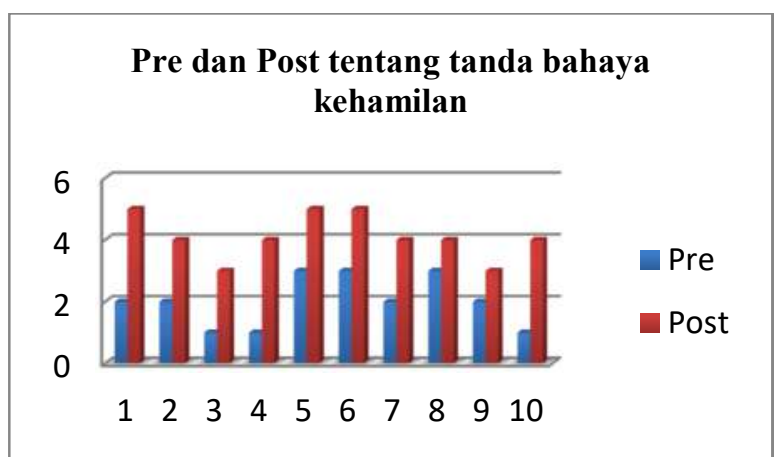

Gambar 1. Diagram pengetahuan ibu hamil sebelum dan sesudah diberikan edukasi

Gambar 1 menunjukkan adanya peningkatan pengetahuan ibu hamil tentang pedoman ibu hamil di era pandemic covid 19 dan tanda bahaya kehamilan sebelum dan sesudah diberikan edukasi. Sebelum Edukasi, ibu hamil sebagian besar salah menjawab tentang masa inkubasi virus covid 19, pedoman bagi ibu hamil saat pandemic covid 19, tanda bahaya kehamilan lanjut dan pertolongan yang dapat diberikan pada ibu hamil dengan tanda bahaya.

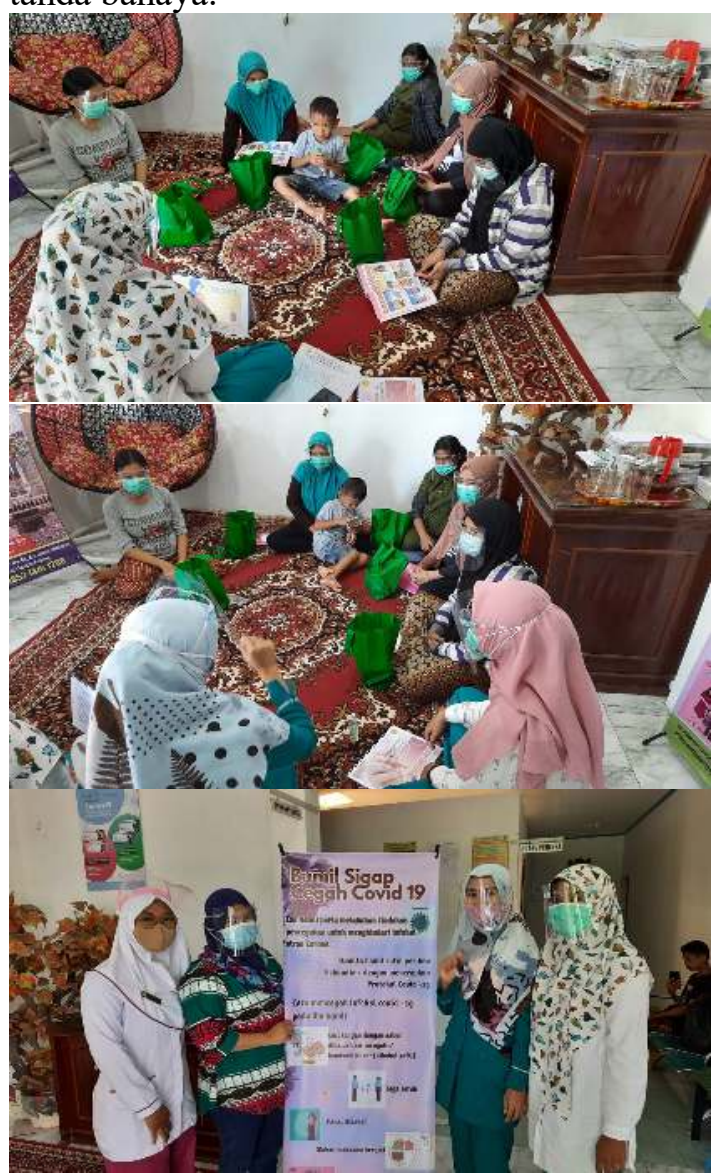

Gambar 2. Dokumentasi kegiatan pengabdian masyarakat 
Pandemi Covid 19 menciptakan protocol baru terhadap pelayanan kesehatan bagi ibu hamil. Untuk meminimalisir kontak dengan orang lain yang dapat menyebabkan penularan coronavirus, pemerintah menyarankan ibu hamil tetap melakukan antenatalcare ke fasilitas pelayanan kesehatan, namun tetap memperhatikan protocol kesehatan dan telah membuat temu janji terlebih dahulu dengan petugasnya atau taupun melalui telepon dan video conference. Ketika ingin melakukan persalinan, ibu akan melalui skrining berupa RT-PCR SARS-CoV-2. Hal ini bertujuan untuk mencegah komplikasi dan penularan virus kepada sang bayi, ibu, maupun kepada dokter/ bidan yang membantu berjalanan persalinan. Ibu yang suspek atau terkomfirmasi akan dilakukan pemisahan sementara dengan anaknya, di mana proses menyusui akan diperantai pengasuh dan ASI tetap dari sang ibu (Direktorat Kesehatan Keluarga, 2020) (Turrentine, M et al, 2020) (CDC, 2020)

Disamping itu, hasil survey kepuasan mitra terhadap kegiatan pengabdian masyarakat ini menyatakan sebagian besar mitra sangat setuju pengabdian masyarakat ini dapat meningkatkan pengetahuan mereka tentang covid 19, pedoman antenatal selama covid 19 dan tanda bahaya kehamilan.

\section{KESIMPULAN}

Koordinasi berjalan dengan baik sehingga diharapkan kegiatan pengabdian ini berjalan dengan baik dan bermanfaat bagi ibu hamil, PMB Silvia Nova Sari. Terjadi peningkatan pengetahuan ibu hamil tentang pedoman ibu hamil di era pandemic covid 19 dan tanda bahaya kehamilan sebelum dan sesudah diberikan edukasi dan sebagian besar mitra sangat setuju pengabdian masyarakat ini dapat meningkatkan pengetahuan mereka tentang covid 19, pedoman antenatal selama covid 19 dan tanda bahaya kehamilan.

\section{SARAN}

Diharapkan informasi dan edukasi tentang pedoman ibu hamil di era pandemic covid 19 dan tanda bahaya kehamilan dapat diteruskan oleh pemilik
PMB kepada ibu hamil lainnya yang tidak dapat mengikuti langsung kegiatan pengabdian masyarakat sehingga ibu hamil di wilayah PMB tersebut meningkatkan kewaspadaan dalam penyebaran virus covid 19 .

\section{UCAPAN TERIMA KASIH}

Terima kasih disampaikan kepada LPPM STIKes MERCUBAKTIJAYA Padang,Prodi S1 Kebidanan STIKes MERCUBAKTIJAYA Padang, tim pelaksana dan mahasiswa pendamping; dan semua pihak yang telah berkontribusi terselenggaranya kegiatan Pengabdian masyarakat ini

\section{DAFTAR PUSTAKA}

[1] POGI, POKJA INFEKSI SALURAN REPRODUKSI. REKOMENDASI PENANGANAN INFEKSI VIRUS CORONA (COVID-19) PADA MATERNAL (HAMIL, BERSALIN DAN NIFAS) . 2020.

[2] WHO. WHO Coronavirus Disease (COVID-19) Dashboard. s.1. : https://covid19. who.int/table, 2020.

[3] KANNAN, S., et al., et al. COVID-19 (Novel Coronavirus 2019) -recent trends. Maldives : European Review for Medical and Pharmacological Sciences, 2020, Vol. 24.

[4] S. Khan, L Jun, Nawsherwan, R Siddique, Y.Li, G.Han, M.Xue, G. nabi, J.Liu. Association of COVID-19 with pregnancy outcomes in healthcareworkers and general women. 6, China: Elsevier, 2020, Clinical Microbiology and Infection, Vol. 26.

[5] Pedro Castro, Ana Paula Matos, Heron Werner, Flávia Paiva Lopes, Gabriele Tonni. Covid-19 and Pregnancy: An Overview. Rio de Jainero Brazil: Thieme Revinter, 2020. 01007203.

[6] Pradip Dashraath, MBBS, MRCOG, Jing Lin Jeslyn Wong, MBBS, MRCOG and Mei Xian Karen Lim, MBBS, MRCOG. Coronavirus disease 2019 (COVID-19) pandemic and pregnancy. Singapore : Elsevier, 2020. 
[7] Humas Kota Padang. Instagram Humas Kota Padang . [Online] 2020. humas.kotapadang.

[8] Direktorat Kesehatan keluarga. PEDOMAN BAGI IBU HAMIL, BERSALIN, NIFAS, DAN BAYI BARU LAHIR Di Era Pandemi COVID-19. Jakarta : Direktorat Jenderal Kesehatan Masyarakat KEMENTERIAN KESEHATAN RI , 2020.

[9] Turrentine, M., Ramirez, M., Monga, M., Gandhi, M., Swaim, L., Tyer Viola, L., Birsinger, M., \& Belfort, M. (2020). Rapid Deployment of a Drive-Through Prenatal Care Model in Response to the Coronavirus Disease 2019 (COVID-19) Pandemic. Obstetrics and Gynecology, 136(1), 1-4. https://doi.org/10.1097/AOG.000000000 0003923

[10] Centers for Disease Control and Prevention. (2020). Protect yourself and your family from COVID-19. USA. Diakses pada tanggal 26 Agustus 2020 dari: https://www.cdc.gov/coronavirus/2019ncov/need-extra-precautions/pregnancybreastfeeding.html 